\title{
Research Paper Determination of technical efficiency in black pepper growing farms in Dindigul district, Tamil Nadu: A non-parametric approach
}

See end of the paper for authors' affiliations

\section{Correspondence to :}

\section{B. SIVASANKARI}

Department of Agricultural Economics, Agricultural College and Research Institute, MADURAI (T.N.) INDIA Email:maranfsn@gmail. com, bsankari2007@ rediffmail.com

\section{Paper History :}

Received : 04.07 .2014

Revised : 30.07.2014;

Accepted: 13.08 .2014
ABSTRACT : This study is carried out to analyze the performance of black pepper farms in Dindigul district by estimating the level of technical efficiency. Data Envelopment Analysis (DEA), a nonparametric method was applied to estimate technical efficiency of black pepper farms. A sample of 100 pepper farmers was selected for this study through field survey that was conducted from 2012-2013 growing season. The technical efficiency index ranged from 0.41 to 1.00 under both Constant Returns to Scale (CRS) and 0.48 to 1.00 under Variable Returns to Scale (VRS) specification. The mean technical efficiencies were 0.76 and 0.81 under CRS and VRS specification, respectively. The scale efficiency ranges between 0.75 and 1.00 with a mean of 0.93 . Of the 100 black pepper farms, nine show constant returns to scale, 81 show increasing return to scale while three show decreasing return to scale. This result shows that there is small scale inefficiency in the study area. There are excess uses for all inputs especially for fertilizers like potash, phosphorus and farm yard manure.

KEY WORDS : Black Pepper, Technical efficiency (TE), Scale efficiency, DEA, CRS, VRS

HOW TO CITE THIS PAPER : Sivasankari, B. and Rajesh, R. (2014). Determination of technical efficiency in black Pepper growing farms in Dindigul district, Tamil Nadu: A non-parametric approach. Internat. Res. J. Agric. Eco. \& Stat., 5 (2) : 266-271. 